\title{
An Evaluation of Listed Companies by Means of Cash Flow Ratios ${ }^{1}$
}

\section{Jooste and G M Dekker}

Graduate School of Management, University of Pretoria

\section{ABSTRACT}

The aim of this study is to determine whether the cash flow statement succeeds in increasing the usefulness of financial data to parties interested in the results of specific companies and related institutions. This South African study uses the same industries as those in a similar study by Giacomino and Mielke (1993) in the USA. The industries concerned are chemicals and oils, food and electronics. Relative performance was measured by calculating nine sufficiency and efficiency ratios. These ratios were calculated for each institution in the industry; weighted averages were also calculated for each industry. The results were compared with the norms developed for American institutions. All the listed South African companies in the industries concerned were included in the study.

JEL M 41

\section{INTRODUCTION}

This study was undertaken to establish whether the cash flow statement succeeds in increasing the usefulness of financial information to decision-makers interested in the results of specific companies and other types of institutions.

Ratios are used in the analysis of financial statements. With the addition of the cash flow statement to other financial statements, a need arose for calculating ratios which would serve to evaluate the results indicated by the cash flow statement. At present there is no complete series of ratios with which to evaluate cash flow statements.

The primary goal of financial reporting, according to AC 000 (Opperman, 1994), is to establish useful financial information for economic decision-making. According to AC 101 (Cilliers, 1995:535), one purpose of the cash flow statement is to supply 
information on the cash flow of an institution. This information would be helpful to the users of financial statement as a basis upon which to form an opinion on the institution's ability to generate cash and cash equivalents, as well as the cash flow needs of the institution. Economic decisions taken by users of financial statements require an evaluation of the ability of an enterprise to generate cash and cash equivalents, the timing thereof and the probability that it will in fact be generated (Cilliers, 1995:535).

An advantage of the cash flow statement, when used together with the rest of the financial statements, is that it supplies information which enables users to evaluate the cash effect of changes in the net assets of an institution, as well as its financial structure (including liquidity and solvency). The cash flow statement also enables users to evaluate the institution's ability to influence the amount and timing of the cash flow, in order to adapt to changing circumstances and opportunities. The cash flow information enables users to develop models to assess and compare the current value of the future cash flows of different institutions. It also facilitates the comparison of sectoral performance, since it eliminates the effect of different accounting conventions on the same transactions and events. Historical cash flow information is also used to indicate the amount, timing and certainty of future cash flow. It is moreover useful for checking the accuracy of previous calculations, the relationship between profitability and net cash flow, and the effect of changing prices (Cilliers, 1995:536).

Independent performance ratios are of limited use. However, when the ratios of one institution are compared with those of others over a number of years, then they become more meaningful (Giacomino \& Mielke, 1988:56). One of the goals of this study is to determine whether the potential exists for developing ratios for industries, in terms of which the relative performance of institutions may be measured. An empirical study was made of institutions in the chemicals and oils, food and electronic industries, from 1994 to 1996. Nine ratios for assessing relative performance were calculated for each institution in the industry, which could be compared with a set of norms developed for this purpose. All the institutions in the particular industry were included in an empirical study to evaluate relative performance. (Table 2 sets out the number of institutions used for the calculation of performance ratios.)

Relative performance evaluation is one of the uses of cash flow ratios, which evaluate the sufficiency and efficiency of the cash flow. Sufficiency means the ability of an institution to provide for its requirements of cash, and efficiency 
means the extent to which cash is generated over time and relative to other institutions (Giacomino \& Mielke, 1988:55)

\section{THE USE OF RATIOS}

Analysts use ratios, inter alia, to evaluate the cash effects of changes in the net assets, financial structure (including liquidity and solvency), and relative performance of an institution. Relative performance evaluation proceeds from the assumption that with the comparison of an institution's performance to a norm, general uncertainties are eliminated and only specific performance with regard to the institution remains. The performance of other institutions then provides information regarding a specific institution's performance (Giacomino \& Mielke, 1993:55).

\section{CASH FLOW RATIOS}

In the cash flow statement, the cash flow from operating activities is a summary of the transactions and events involved in the determination of net income. Operating activities are the primary activities of an institution. Cash flow from operating activities is a component of each ratio used to evaluate relative performance. In this study norms were calculated for each ratio based on the cash flow. This was done by expressing the industry ratios as weighted averages over the three year period 1994-1996. The components and interpretation of the ratios are summarised in Table 1.

Table 1: Summary of Ratios

\begin{tabular}{|l|l|l|l|}
\hline Name of ratio & Components of ratios & Interpretation of ratios \\
\hline \multicolumn{3}{|c|}{ Sufficiency Ratios } \\
\hline sufficiency flow & $\begin{array}{l}\text { Cash from operating } \\
\text { activities/ ( long-term debt } \\
\text { repayments + purchasing } \\
\text { of assets + dividends paid) }\end{array}$ & $\begin{array}{l}\text { Evaluates an institutions } \\
\text { ability to generate sufficient } \\
\text { cash to meet primary } \\
\text { obligations }\end{array}$ \\
\hline $\begin{array}{l}\text { Long-term debt } \\
\text { repayment }\end{array}$ & $\begin{array}{l}\text { long-term debt repayment } \\
\text { fash from operating } \\
\text { activities }\end{array}$ & $\begin{array}{l}\text { Evaluates the sufficiency of } \\
\text { cash flow to settle long-term } \\
\text { debt }\end{array}$ \\
\hline
\end{tabular}


Table 1 continued

\begin{tabular}{|c|c|c|}
\hline Name of ratio & Components of ratios & Interpretation of ratios \\
\hline \multicolumn{3}{|c|}{ Sufficiency Ratios } \\
\hline Dividend pay-out & $\begin{array}{l}\text { Dividends paid } / \text { cash } \\
\text { from operating activities }\end{array}$ & $\begin{array}{l}\text { Evaluates the sufficiency of } \\
\text { cash flow to pay dividends }\end{array}$ \\
\hline Reinvestment & $\begin{array}{l}\text { Purchasing of assets / cash } \\
\text { from operating activities }\end{array}$ & $\begin{array}{l}\text { Evaluates the sufficiency of } \\
\text { cash flow for reinvestment } \\
\text { and maintaining the asset } \\
\text { structure }\end{array}$ \\
\hline Debt cover & $\begin{array}{l}\text { total debt / cash from } \\
\text { operating activities }\end{array}$ & $\begin{array}{l}\text { Estimates the number of } \\
\text { years to repay debt at the } \\
\text { current level of cash flow }\end{array}$ \\
\hline $\begin{array}{l}\text { Impact of } \\
\text { depreciation } \\
\text { write-offs }\end{array}$ & $\begin{array}{l}\text { (depreciation + amounts } \\
\text { written off) / cash from } \\
\text { operating activities }\end{array}$ & $\begin{array}{l}\text { Evaluates the percentage } \\
\text { cash from operating } \\
\text { activities due to adjustments } \\
\text { and amounts written off }\end{array}$ \\
\hline \multicolumn{3}{|c|}{ Efficiency Ratios } \\
\hline $\begin{array}{l}\text { Cash flow to } \\
\text { sales }\end{array}$ & $\begin{array}{l}\text { Cash from operating } \\
\text { activities / sales }\end{array}$ & $\begin{array}{l}\text { Indicates the percentage of } \\
\text { each one rand-sale from } \\
\text { operating activities which is } \\
\text { realised as cash flow }\end{array}$ \\
\hline Operating index & $\begin{array}{l}\text { Cash from operating } \\
\text { activities / income from } \\
\text { continued activities }\end{array}$ & $\begin{array}{l}\text { Compares cash flow from } \\
\text { operating activities with } \\
\text { income from continued } \\
\text { activities }\end{array}$ \\
\hline $\begin{array}{l}\text { Cash flow on } \\
\text { assets }\end{array}$ & $\begin{array}{l}\text { cash flow from operating } \\
\text { activities / total assets }\end{array}$ & $\begin{array}{l}\text { Evaluates the cash flow from } \\
\text { assets utilised }\end{array}$ \\
\hline
\end{tabular}

The sufficiency and efficiency ratios in Table 1 are examples of the kind of information which is available from the cash flow statement to the users of financial statements.

In Table 1 cash from operating activities is measured before dividends. For the purchase of assets, the gross acquisition of assets is used in the calculation of the ratio. Depreciation and other sums written off include losses on the sale of assets and other sums written off on assets 
Table 2: Numver of Institutions in Industry

\begin{tabular}{|c|c|c|c|}
\hline Year & Chemicals and Oils & Food & Electronic \\
\hline 1996 & 11 & 27 & 34 \\
1995 & 10 & 25 & 31 \\
1994 & 8 & 23 & 27 \\
\hline
\end{tabular}

According to Table 2, the companies in the industries which were analysed differed from year to year. The reason for this is that some excising companies were delisted while new companies came to be listed on the Johannesburg Stock Exchange. The weighed averages over three years were taken as the norms for the ratios of an industrial sector.

\section{EMPIRICAL RESULTS}

The chemicals and oils, food and electronic industries were used in the present study, since these are the same as the industries used by Giacomino and Mielke (1993:55-8) in a study in the USA. In Table 3, the 3-year weighted average (used as the norm) is set out for each industry.

Table 3 gives the norms for the ratios of the industries concemed. The ratios of individual institutions based on their respective norms may be used, to evaluate their respective performances.

Table 3: Norms for Ratios per industry

\begin{tabular}{|l|c|c|c|}
\hline \multicolumn{1}{|c|}{ Ratio } & \multicolumn{3}{c|}{ Three-year averages 1994 -1996 } \\
\hline & $\begin{array}{l}\text { Chemicals } \\
\text { and oils }\end{array}$ & Food & Electronics \\
\hline \multicolumn{3}{|c|}{ Sufficiency Ratios } \\
\hline Cash flow sufficiency & 1,85 & 1,49 & 1,94 \\
\hline Long-term debt repayment & 0,88 & 0,60 & 0,24 \\
\hline Dividend pay-outs & 0,09 & 0,14 & 0,16 \\
\hline Reinvestment & 0,51 & 0,50 & 0,42 \\
\hline Debt cover & 2,52 & 3,27 & 3,18 \\
\hline
\end{tabular}


Table 3 continued

\begin{tabular}{|l|c|c|c|}
\hline \multicolumn{1}{|c|}{ Ratio } & \multicolumn{1}{|c|}{ Three-year averages 1994-1996 } \\
\hline & $\begin{array}{l}\text { Chemicals } \\
\text { and oils }\end{array}$ & Food & Electronics \\
\hline \multicolumn{3}{|c|}{ Sufficiency Ratios } \\
\hline $\begin{array}{l}\text { Impact of depreciation } \\
\text { write-offs }\end{array}$ & 0,22 & 0,23 & 0,18 \\
\hline \multicolumn{4}{|c|}{ Efficiency Ratios } \\
\hline Cash flow to sales & 0,17 & 0,09 & 0,08 \\
\hline Operating index & 0,95 & 0,89 & 0,85 \\
\hline Cash flow on assets & 0,21 & 0,17 & 0,18 \\
\hline
\end{tabular}

An analysis was made of the data obtained from the Bureau for Financial Analysis (BFA) at the University of Pretoria. Each ratio was analysed over three years, to determine whether there had been an increase and/or a decrease from year to year. Individual institutions in an industry were evaluated by comparing their performance with the norm for each ratio. An institution cannot be evaluated by only looking at isolated ratios. A comparison with other institutions, the averages of the industry concerned, institutions from other industries and the relevant norms are however more informative (Giacomino \& Mielke, 1988:56). Relative performance evaluation proceeds from the assumption that when an institution's performance is compared with that of an industry or a norm, this eliminates the effect of general uncertainties in performance and only leaves specific performance of the institution (Giacomino \& Mielke, 1993:55). The results are discussed next.

\subsection{Cash Flow Sufficiency Ratio}

The cash flow sufficiency ratio indicates the adequacy of an institution's cash flow from operating activities to cover its long-term payments, purchase of assets and payments of dividends. Giacomino and Mielke $(1993,56)$ consider a ratio of one as a reasonable target. 
An analysis of the cash flow sufficiency norms in Table 3 indicates that the industries had indeed generated enough cash to cover their primary cash requirements. In all cases the norm for the industries is more than one.

After the analysis of the cash flow sufficiency ratios of individual institutions, the following conclusion was derived: In the chemicals and oils industry, four institutions in 1996, one in 1995 and two in 1994 did not have sufficient cash flow from operating activities to cover primary cash flow obligations. Likewise in the food industry seven institutions in 1996, ten in 1995 and nine in 1994 did not have sufficient cash flow. In the electronics industry ten institutions in 1996 and 1995 and four in 1994 did not meet this requirement. In 1996 four institutions in the chemicals and oils industry, fourteen in the food industry and fifteen in the electronics industry had a cash flow ratio higher that that of the industry for three years.

The average over three years for chemicals and oils, food and electronics, was 1,85 ; 1,49 and 1,94 respectively. If these figures are taken as the norm, analysts may measure an individual institution's performance on the basis of the norms of the industry in question, and also those of other industries. Causes of significant differences may have to be sought. In the event, the long-term debt repayment, dividend pay-out and reinvestment ratios may possibly be used. The latter ratios are components of the cash flow sufficiency ratio, and may thus indicate the causes of the observed differences.

\subsection{Other Ratios which Relate to Cash Flow Sufficiency}

In Table 3, an analysis of the long-term debt repayment, dividend pay-out and reinvestment ratios per industry indicates, with one exception, that there were hot more pay-outs than the cash flow from operating activities. The average of the chemicals and oils industry in 1994, indicates that the repayment of long-term debt was more than the cash flow from operating activities.

The long-term debt repayment, dividend pay-out and reinvestment ratios, each represent a component of the denominator in the cash flow sufficiency ratio. The ratios per industry (Table 3 ) are discussed in paragraphs 5.2.1 to 5.2.3. A summary is given in paragraph 5.2.4. 


\subsubsection{Industry: Chemicals and Oils}

In the chemicals and oils industry, the average of the three ratios decreased over the three years. There was a decrease of $23,5 \%$ in long-term repayment of debt, $66,7 \%$ decrease in the payment of dividends and $33,8 \%$ decrease in reinvestment, in relation to cash flow from operating activities. In 1996 there were two institutions, and in 1995 and 1994 one institution, that repaid more long-term debt than what the cash flow from operating activities had been. No institution paid more dividends than their cash flow from operating activities. Two institutions in 1996 and 1994 and one in 1995, reinvested more than their cash flow. These appeared to be the same institutions as those which repaid their long-term debt.

The ratios of the individual institutions in 1996 indicate that three institutions' repayment of long-term debt, and six institutions' dividend pay-out and reinvestment ratio were higher than the corresponding norms.

\subsubsection{Industry: Food}

The food industry appears to show the same tendency as chemicals and oils, although the percentage decreases were less for the three years. The decrease in repayment of long-term debt was $9,6 \%$, dividend pay-out $29 \%$ and reinvestment $21,7 \%$. Six institutions in 1996, six in 1995 and five in 1994, had more repayments of long-term debt than their cash flow from operations. In other words, these institutions had a negative cash flow.

Six institutions in 1995, four in 1996, and three in 1994 reinvested more than the cash flow from operating activities

A comparison of the institutions in 1996 with the norm of the industry in Table 3, indicates that seven institutions' repayment of long-term debt, and thirteen institutions' payments of dividends and reinvestment were higher either than or equivalent to the norm.

\subsubsection{Industry: Electronics}

In the electronics industry there appears to have been a decrease in the repayment of long-term debt and payments of dividends of $9,6 \%$ and $29 \%$ respectively. Reinvestment increased by $70 \%$ in 1995 and decreased by $19,6 \%$ in 1996 , where the global increase was $36,7 \%$. Three institutions in 1996, four in 1995 and one in 
1994 had more repayments of long-term debt than cash flow from operating activities. Of these institutions, one had been present for three years. The same three institutions were present in 1996 and 1995, of which one institution had existed for only two years. Three institutions had made more dividend payments than their cash flow over the three-year period. Two of the institutions had a negative cash flow and one institution had existed for only one year. Five institutions in 1996 and four in 1995 had increased their reinvestment in assets. Two of the companies had a negative cash flow.

The long-term repayment of debt, dividend pay-out and reinvestment ratios of the various institutions in the three industries, were compared with the respective norms in Table 3. The comparison indicated that eight firms in chemicals and oils, seventeen in food and ten in electronics had specific ratios higher than or equal to the industry norms.

\subsubsection{Evaluation of the industries}

An analysis of the industrial average used as the norm (Table 3 ), shows that chemicals and oils, and food spent the greatest portion of their cash flow from operating activities on the repayment of long-term debt. Electronics spent most of its cash flow on reinvestment. In all three industries, the smallest portion was paid out in dividends. It appears that over the three-year period, a total of five institutions made more dividend payments than their cash flow from operating activities. In 1996, one institution had existed for only one year, and four institutions had a negative cash flow.

The norm for dividend payments of varies from $9 \%$ to $16 \%$ for the three industries. A possible conclusion with regard to the decrease in dividend payments may be that institutions tend to distribute less profits. This appears to be the case in all three industries.

Enlightened conclusions may be drawn from the three ratios. If norms are established for industries, the performance of institutions may be assessed on the basis thereof. A specific ratio for an institution may be compared with the average for the industry in a given year, or with the averages of other institutions in the industry for one, two or three years.

The long-term debt repayment, dividend pay-out and reinvestment ratios provide insight into the individual significance of these three items. The three ratios may 
be expressed as percentages and added together. This indicates the percentage cash flow from operating activities which is available for discretionary use. If the analysis is done on the basis of the norms in Table 3, only the electronics industry has any remaining cash flow from operating activities for discretionary use. This may also serve as a norm to which institutions in the industries may be compared.

\subsection{Long Term Debt Repayment Ratio}

Although an institution may generate cash from investment and financing activities to repay debt, cash flow from operating activities is the main source of long-term funds. The repayment of debt ratios for the three industries in Table 3 were reasonably constant over time. An increase in the repayment of debt ratio may indicate a decrease in the repayment of long-term debt and an increase in debt. Both food and electronics experienced a decrease in repayments of long-term debt.

A comparison of the institutions in the industry with the norm, indicated that the ratios of six institutions from chemicals and oils and food, and fifteen from electronics were below the norm. The denominators of three institutions were negative, indicating that they had negative debt, and were not included in this calculation.

\subsection{Impact of Depreciation Write-Off Ratio}

The impact of the depreciation write-off ratio indicates the percentage of cash flow from operating activities which arises from the adding back of depreciation, adjustments and other write-offs. The three-year average ratios in Table 3 were in fact relatively constant. This may indicate that the industries have the capacity to maintain asset structures.

Over the period 1994-1996 there was only one institution from the food industry and three from electronics, where the impact of the depreciation write-off ratio was more than the cash flow from operating activities. A comparison of the institutions in 1996 with the norm in Table 3, indicates that the ratio of six institutions in the chemicals and oils, eight institutions in the food and fourteen institutions in the electronic industry was greater than or equivalent to the norm. Three institutions had a negative denominator and were excluded from the calculation.

The reinvestment ratio may be used to determine whether reinvestment occurs at a higher or lower level than the writing-off/depreciation of assets (Giacomino \& 
Mielke, 1993:57). A comparison of the impact of the write-off ratio on the reinvestment ratio provides insight into the sufficiency of an institution's reinvestment and the maintenance of its asset structure. Over a number of years the reinvestment ratio should exceed the impact of the depreciation/write-off ratio, This would ensure that there is adequate replacement of assets at current increased costs. In the three industries, it does in fact appear from Table 3 that the asset structure has been either maintained or increased. The ratio may also be used to evaluate efficiency. An institution would be considered the more efficient if its write-off ratio has a relatively low impact on the cash flow from operating activities.

\subsection{Cash Flow to Sales Ratio}

The cash flow to sales ratio is an efficiency ratio. It indicates the percentage of each rand's worth of sales which has been realised as cash flow from operating activity. Over a period, the ratio should indicate an institution's return on sales (Giacomino \& Mielke, 1993:56).

When the norms of cash flow to sales ratio of the industries are compared with each other, some meaningful conclusions may be drawn. According to Giacomino and Mielke (1993: 58) the food industry had a lower earnings on sales than chemicals and oils, and electronics. If the food industry is compared with chemicals and oils, in Table 3, this is in fact the case. When comparing the food and electronics industry, it does not appear to be the case. The electronics industry, on the other hand, shows a lower cash flow to sales than food, and chemicals and oils.

The industry's norm was used to evaluate the individual institutions. In 1996 it appears that the cash flow to sales of four institutions in chemicals and oils, sixteen in the food and nineteen in the electronics industry, was better than the norm for the different industries.

\subsection{Operating Index Ratio}

The operating index ratio compares the cash flow from operating activities with the income from continued operations. The ratio measures the capacity to generate cash from continued operating activities. The ratio is also useful when it is compared with income from continued operations. It shows the extent to which non-cash transactions are involved in the calculation of operating income. Over a number of years it may be expected that cash flow from continued operating 
activities should be more or less equal to income from continued operations. The operating index ratio makes such comparison possible (Giacomino \& Mielke, 1993:58).

When the institutions comprising an industry are measured against the industrial norm in Table 3 , there are to be only 18 cases over 3 years where the cash flow from operating activities was equal to or more than the norm for income from continued operations. If the figures for 1993 are also taken into account, the two variables over an average of four years are still not equal to each other. According to Table 3 , the norm for chemicals and oils $(0,95)$ is the highest, compared to food $(0,89)$ and electronics $(0,85)$. It appears that the ratio for all the industries has declined during 1994-1996. Only electronics showed an increase in 1995.

Individual institutions may also be compared with the norm, as well as the industry trend. The trend appears to be decreasing over the three years. As in the previous discussions, individual institutions may be measured against the industrial norm.

\subsection{Cash Flow on Assets Ratio}

The cash flow on assets ratio measures the return on the assets used. It is used to compare institutions in terms of the cash generated from assets (as against the income produced) (Giacomino \& Mielke, 1993:56). When cash flow from operating activities is compared with total assets, it appears that there was a reasonably constant return on assets per industry over the three years. According to Table 3, there was an increase in the norm of 0,01 in chemicals and oils in 1995. Food decreased in 1996 by 0,01 . Electronics increased by 0,01 in 1995 and decreased by 0,03 in 1996 . This $3 \%$ decrease might be ascribed to the increase in reinvestment in 1995 (Giacomino \& Mielke, 1993:58)

When a comparison is made of institutions with the industrial norm in 1996, it appears that six institutions in chemicals and oils, sixteen in food and twenty in electronics had a cash flow return on assets equal to or more than the industrial norm.

\section{COMMENTS}

No specific institution was analysed in this study; analysis was done in general. Firstly the norms of the industries were compared with each other to determine 
evident tendencies. For example: it appears that the dividend payment norm relative to cash flow may be low in all the industries. It also appears that repayment of long-term debt was significantly higher in the chemicals and oils industry than in the electronic industry. The debt cover ratio in food appears to be the highest of the three industries. Electronics again appears to be the only industry which had any cash flow left for discretionary use. In the efficiency ratios there are remarkable differences in cash flow to sales. It is significantly higher in chemicals and oils than food and electronics, for all three years.

The next step was to compare the institutions in an industry with the norm. The question of how many institutions fared better, the same or worse than the norm, was also considered. To evaluate performance, an institution should not just be evaluated against one norm, but against a series of norms (for ratios) and also other institutions. If the cash flow sufficiency ratio of one institution is higher than the norm of other institutions, it does not necessary follow that the first-mentioned institution's financial performance has been the best. A reason for this might be that long-term repayment and reinvestment was comparatively low. A low reinvestment ratio could indicate that an institution does not replace or increase assets. If an institution has to maintain or increase an assets structure, the reinvestment ratio must exceed the depreciation write-off ratio for some years. The cash flow return on the assets of an institution, on the other hand, may be lower than the norm and that of other institutions. A possible cause of this may be that reinvestment has increased.

Giacomino and Mielke (1993:58) suggest that in cases where norms of industries differ significantly, cut-off values for industries should be established. For all other ratios, it is suggested that inter-industry averages be developed.

\section{CONCLUSIONS}

In this study, nine ratios based on cash flows were used to evaluate relative performance on the basis of sufficiency and efficiency ratios. These ratios furnish additional information (over and above the traditional financial ratios) about the ratio between cash flow from operating activities and other significant industrial variables. The ratios become more useful in the determination of averages and tendencies when they are calculated over a period of years, and particularly when they are compared with industrial norms. 
Several comparisons were made in this study. Ratios for the institutions in an industry were compared with the norm for the industry. The users of financial statements may supplement the data obtained from traditional analysis of these statements, by using information derived from the cash flow statement. Cash flow ratios may, inter alia, be used to evaluate the financial performance of institutions in terms of financial strength and profitability. Sufficiency ratios measure the ability of an institution to comply with its obligations. Efficiency ratios for a given year, may be used to determine whether an institution has generated enough cash in relation to other years and to other institutions.

The ratios in this study were calculated from operating activities. This is the primary activity of an institution, and in difficult economic times it is cash flow in particular, rather than operating profit, that determines the viability of an institution. Up to now very little has been done to develop an extensive set of ratios which measures financial performance. It has been suggested, inter alia, by Giacomino and Mielke (1993), that cash flow ratios should serve as a starting point for the development of ratios which are based on cash flow and furnish a basis for general analysis. Currently there is little agreement on precisely which ratios represent the most applicable measures. Time and experimentation with several alternatives should determine which ratios give the best quality of information in the cash flow statement.

This study used the same industries in South Africa as the analysis by Giacomino en Mielke (1993) in the United States of America. Based on the evaluation of the food industry in the last-mentioned study, Juchau and Ross (1994) made a comparative study of the Australian food industry. A South African industry might also come to form part of a similar analysis.

The present study supplies information on the potential value of ratios based on cash flow. Seemingly unlimited scope exists for further research, such as:

- the development of a framework for financial analysis by ratios, which identifies the usefulness/suitability of individual ratios and selects applicable ratios for economic decision-making;

- the development of an extensive series of cash flow ratios which evaluates financial strength and profitability in conjunction with traditional ratios;

- the development of norms for industries, in terms of which the institutions in an industry may be compared; 
- the development of cut-off values for industries where norms significantly differ between the industries; and

- the development of inter-industry averages where the norms of the industries are relatively similar.

Although the cash flow statement focuses mainly on the capacity of an institution to generate positive cash flow from normal operations, it does not provide a complete assessment of the liquidity and viability of an institution. This must be supplemented by other aspects in the financial statements, to furnish a more complete assessment of the ability of a company to generate and use cash.

\section{ENDNOTE}

Based on an MCom (Accounting Sciences) dissertation completed at the University of Pretoria.

Information from the data bank of the Bureau for Financial Analysis was extensively used for this study.

\section{REFERENCES}

1. Opperman, H.R.B. et al. (1994), Rekeningkundige Standpunte en Riglyne. Kenwyn: Juta.

2. Cilliers, H.S. et al. (1995), Maatskappy Finansiële State in Konteks. Durban: Butterworths.

3. Giacomino, D.E. and Mielke, D.E. (1988), "Using the Statement of Cash Flows to Analyse Corporate Performance", Management Accounting, pp. 5457.

4. Giacomino, D.E. and Mielke, D.E. (1993), "Cash Flows: Another Approach to Ratio Analysis", Journal of Accountancy, March, pp. 55-58.

5. Juchau, R. and Ross, P. (1994), "Putting Cash into Ratios", Australian Accountant, November, pp. 29-31. 